Also comprised in the Australian flora are temperate species with northern hemisphere affinities. Some of these occur in temperate communities in both hemispheres, but others are endemic to, and characteristic of, the 'Eremran' zone. It is thought that the flora of this zone may have originated from a coastal sand dune and littoral type; and it is suggested that it developed from elements that migrated to the Australian region as early as the Cretaceous when there may have been a coastal continuity with the Tethys Sea. A further suggestion is that these plants remained in coastal habitats but moved inland, possibly along southern estuarine coasts, and became isolated under arid conditions during the Pleistocene or Recent times.

From Dr. Burbidge's analysis, it appears that eastern Australia "has been a very important migration route for a very long period, being linked with the northern hemisphere through Malaysia". The northward migration of Australian species has apparently been less successful than the southward migration of Malaysian ones, the ecological barrier afforded by dense tropical communities having inhibited the northward movement of the light-requiring Australian types: "The significance of such a barrier would be dependent on the climatic conditions during periods of land continnity between Australia and Malaysia and between Australia and New Guinea".

The view that Australia and New Zealand are constituent parts of a biogeographic region is regarded by Dr. Burbidge as unacceptable, unless such a region includes a portion of the island arc in the northeast.

\title{
THE WATER NET, HYDRODICTYON
}

\begin{abstract}
$\mathrm{T}$ HE water net, Hydrodictyon reticulatum, occurs only sporadically in Britain, but thanks to its ready growth in culture, the remarkable structure and unusual asexual reproduction of this rare alga have become familiar to many generations of students. Certain details of the life-history were hitherto obscure, however, and even less was known of other species of the genus. Our knowledge of the only three well-defined species, all occurring in South Africa, has now been greatly extended by the recent publication by Dr. M. A. Pocock ( $J$. South African Bot., 27, $167 ; 1960$ ) of the results of detailed investigations which were in progress for a period of some twenty-five years. In addition to repeated examinations of materials collected in the field, extensive use was made of culture methods, the adoption of agarplate cultures making it possible to follow the fate
\end{abstract} of individual cells and cœnocytes.

In all three species of Hydrodictyon the basic structure is a network of cœnocytes, each with many nuclei and conspicuous pyrenoids; but whereas in $H$. reticulatum (L.) Lagerheim the mature net is an elongated hollow cylinder, in the other two species (H. africanum Yamanouchi and $H$. patenaeforme Pocock) the cœenocytes form a flat typically onelayered plate. In $H$. reticulatum and $H$. patenaeforme the cœnocytes remain cylindrical, while in $H$. africanum they become spherical and dissociate, the individual cœnocytes developing independently for a considerable time.

In addition to these differences in the mature net, the three species differ in the details of their lifehistories. It has long been known that in the asexual reproduction of $H$. reticulatum the protoplast of each conocyte divides into a large number of uninucleate zooids, which without being liberated rearrange themselves and unite to form a new net in the parent cœnocyte. There have been several differences of opinion as to certain details of this process, but the investigations of Dr. Pocock have clarified many points. In particular, it was found that at one stage in the process the zooids move freely among one another, all protoplasmic connexions between them having disappeared. Although the zooids are confined between the outer protoplasmic membrane and the vacuolar membrane, forming a single peripheral layer, they do not adhere to either membrane. The vacuolar membrane persists throughout net formation, finally disappearing when the young net is liberated by the rupture of the outer wall. There is no asexual reproduction of this type in the other species of Hydrodictyon, where daughter nets are never produced within mature conocytes.

In $H$. patenaeforme and $H$. africanum the mature cœnocytes produce swarmers which are always liberated into the water. The swarmers of $H$. patenaeforme may either behave as gametes, fusing in pairs to form first a planozygote which finally becomes a hypnospore, or may act as asexual spores producing hypnospores without previous fusion. As in the earlier known sexual process of $H$. reticulatum, the gametes are isogamous. In $H$. africanum the gametes are anisogamous and there is still some doubt as to whether they can act as asexual spores. The asexual production of hypnospores is found only occasionally in $H$. reticulatum.

The hypnospores of all species, whether sexually produced (zygospores) or asexually (azygospores), may enter a prolonged resting phase or may germinate at once following a period of growth. In $H$. reticulatum and $H$. patenaeforme the hypnospores on germination produce comparatively large zoospores, one from azygospores, typically four or eight from zygospores. After a period of motility, each zoospore settles down and gives rise to a polyhedron stage. Following a period of growth the polyhedron in turn divides to form zooids, which unite to produce the germ net. In $H$. africanum, although polyhedra are occasionally formed, the zoospore and polyhedral stages are usually cut out of the life-cycle. In this species the germ net is produced directly on germination of the hypnospore.

From the details of the life-history and from what is known of the cytology of $H$. reticulatum, it seems clear that in all three species the net is haploid, with the zygospore as the only diploid phase in the lifehistory, reduction division occurring on germination of the zygospore. The polyhedron is an interpolated vegetative phase, peculiar to the family Hydrodictyaceae.
A. Allsopp 